\title{
Evaluation on the Effect of Fishery Insurance Policy: Evidence Based on Text Mining
}

\author{
Xinyi Wei ${ }^{1}$, Qiuguang $\mathrm{Hu}^{1,2,3, *}$ and Jintao $\mathrm{Ma}^{1}$ \\ 1 Business School, Ningbo University, Ningbo 315211, China; 2001010006@nbu.edu.cn (X.W.); \\ moshanke@163.com (J.M.) \\ 2 Port Economy Collaborative Innovation Center, Ningbo University, Ningbo 315211, China \\ 3 Donghai Institute, Ningbo University, Ningbo 315211, China \\ * Correspondence: huqiuguang@nbu.edu.cn
}

Citation: Wei, X.; Hu, Q.; Ma, J. Evaluation on the Effect of Fishery Insurance Policy: Evidence Based on Text Mining. Fishes 2021, 6, 41. https://doi.org/10.3390/ fishes6030041

Academic Editor: Greg G. Sass

Received: 12 July 2021

Accepted: 10 September 2021

Published: 13 September 2021

Publisher's Note: MDPI stays neutral with regard to jurisdictional claims in published maps and institutional affiliations.

Copyright: (c) 2021 by the authors. Licensee MDPI, Basel, Switzerland. This article is an open access article distributed under the terms and conditions of the Creative Commons Attribution (CC BY) license (https:// creativecommons.org/licenses/by/ $4.0 /)$.

\begin{abstract}
As a quasi-public product, fishery insurance has become an important starting point for the construction of the modern fishery industry chain, supply chain and value chain risk management mechanism. We used visual data processing methods and text mining technology to screen policy samples. We then built a fishery insurance policy evaluation system based on the Policy Modeling Consistency (PMC) index model. We combined the PMC index score and PMC surface to quantitatively analyze the policy samples. This paper has four important findings: (1) After three adjustments and developments, the fishery insurance policy has grown in terms of initial attention, changes, and development and gradually matured. (2) A gap exists between the content of the fishing insurance policy text and the actual demand. The scoring results of the policy samples are concentrated in the acceptable range, the policy effects are not satisfactory, and the formulation of fishery insurance policies has weak links that need to be improved. (3) The consistency and effectiveness of fishery insurance policies have developed simultaneously with fishery insurance research, and the practical effects of high-quality fishery insurance policies are conducive to the development of theoretical research. (4) The policy text of fishery insurance has major problems, such as missing joint force of issuing institutions, low professionalism of the text, inadequate subdivision guidance of fishery insurance, weak social effectiveness, high dependence on financial subsidies, lack of incentive sustainability and corresponding laws and regulations and reduction in policy feasibility among others. Considering the above issues, this paper puts forward relevant policy optimization paths and safeguard measures on the basis of giving priority to greater absolute value.
\end{abstract}

Keywords: fishery insurance; policy evolution; text mining; PMC index; effect evaluation

\section{Introduction}

In 2021, the No. 1 Central Document "China to fully advance rural vitalization and facilitate modernization of agriculture and rural areas" mentioned agricultural insurance many times in the contexts of accelerating agricultural modernization and implementing rural construction actions. Agricultural insurance, including fishery insurance, has become an important starting point for the revitalization strategy. As the core mechanism of managing risks within fishery, fishery insurance provides economic compensation for economic losses caused by natural disasters and accidents in the production and operation of fishery producers, such as aquaculture, fishing, processing, storage, and transportation. Fishery insurance includes policy fishery insurance and commercial fishery insurance. The former relies on national policy support, mainly in the form of financial subsidies, to provide certain economic compensation for casualties in fishery production and old-age medical care. The latter is for profit, and special insurance companies run fishery insurance affairs through contracts. In China's legislation, agricultural insurance usually only refers to policy insurance [1], including prior agricultural subsidies and post-agricultural disaster relief [2]. Fishery insurance should not only fully infiltrate the primary industry but also 
focus on innovation and comprehensively build a risk management mechanism that serves the modern agricultural industrial chain, supply chain, and value chain [3]. Therefore, resources allocation must not only rely on the market mechanism but also the government's macro control to avoid market failure [4]. However, owing to the lack of professional risk assessment, coupled with the lack of evaluation research on the efficiency and effectiveness of government support for fishery insurance [5], the existing fishery insurance has been unable to effectively play the role of risk prevention mechanism [6]. Therefore, studying the policy effect of fishery insurance by using scientific methods based on the practice of fishery insurance development is of great significance so as to provide an empirical basis for the policy formulation and implementation of fishery insurance.

\section{Practical Evolution of Fishery Insurance Policy and Literature Review}

After 40 years of development, the main body of fishery insurance in China has changed from a commercial insurance institution to a fishery mutual insurance association guided by the government. After the Ministry of Agriculture and Rural Affairs issued a notice to promote the reform of the fishery mutual insurance system in 2020 [7], the mutual insurance business is spun off from the association and managed by a professional organization. The main body of fishery insurance is once again facing a new opportunity of transformation. The field of fishery insurance research is becoming gradually mature. Based on the literature search in the China National Knowledge Infrastructure database, 421 papers on domestic fishery insurance, including fishery insurance policy, are published as of March 2021 (see Figure 1). Fishery insurance, fishery mutual insurance and policyoriented fishery insurance are the top three topics that scholars focus on.

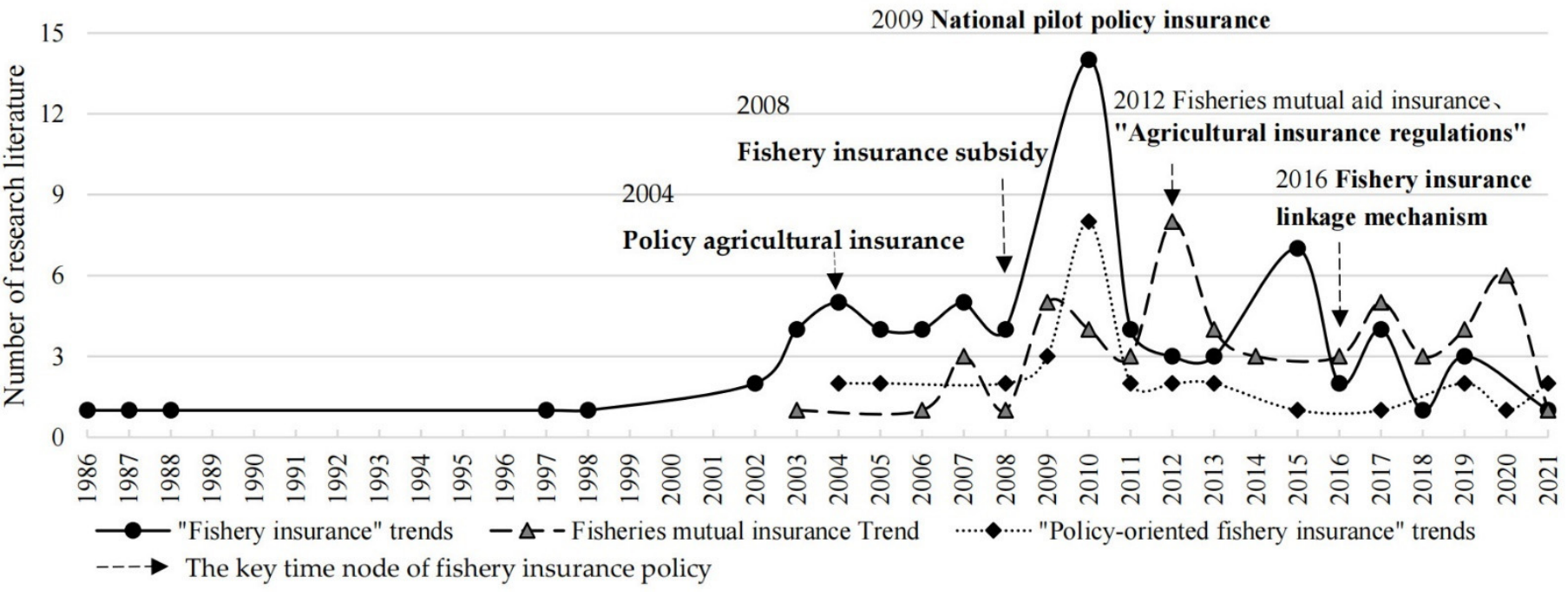

Figure 1. Text statistics of fishery insurance-related research.

Fishery insurance started in November 1981. The People's Insurance Company of China issued the "Domestic Fishing Vessel Insurance Clause". For the first time, relevant regulations for fishery insurance appeared. The fishery insurance market was dominated by commercial institutions $[8,9]$. Research on fishery insurance remains rare in the academic circles at this stage.

From 1986 to 2003, the national fishery insurance policy was not mature. There was only one policy document related to ship safety supervision and management, which did not involve the guidance of fishery insurance [10]. Scholars did not study the national fishery insurance policy, they focused mainly on the trial experience of fishery insurance, exploring development prospects and learning from foreign experience. The first research literature on the actual experience of local fishery insurance [11] summarized the management experience of establishing fishery insurance institutions through collaboration 
between law enforcement and fishery technical professionals In 1997, Ge G.H. found that state-owned commercial insurance companies occupied a decisive position in the fishery insurance market, but the existing fishery insurance system and policies were not conducive to the development of fishery insurance [12]. In 2001, some researchers suggested establishing national policy fishery insurance companies and reinsurance companies in fishery insurance, some of which could be classified as policy-oriented fishery insurance businesses. [13]. Sun Y.S. et al. (2003) suggested that China should pay attention to legislation, enforce partial insurance and provide tax exemption policy after comparing the fishery insurance systems of Japan and South Korea [14]. During this period as well, foreign scholars focused on the "natural insurance" function of fisheries [15] and discussed the international experience of marine protected areas and their insurance performance in fishery management [16,17]. Murray, S.N. et al. (1999) believed that the network of prohibited protected areas can play the insurance function of maintaining fishery stocks and marine ecosystems [18]. Since 2003, the development of fishery mutual insurance associations in various parts of China has become increasingly mature. The first research with the main theme of fishery mutual insurance summarizes the problems: Local mutual insurance business was limited, the management system was weak, and the government did not pay enough attention to it. The mutual insurance system needs financial support [19]. Kong Q.Y. (2002) put forward a proposal for the construction of a state-supported fishery mutual insurance system [20]. Jin L.G. et al. (2003) believed that China's fishery insurance system needs national supportive policies rather than pure financial subsidies [21]. The period from 1986 to 2003 was the preliminary period of fishery insurance and national fishery insurance policy. During this period, policy guidance was not yet mature, but the policy consciousness of fishery insurance was growing. By the end of the period, academic research on the policy system of fishery insurance had shifted from initial attention of the topic to discussion of the best ways to design and implement such policy.

In 2004, "policy-oriented agricultural insurance" appeared for the first time in the No. 1 document of the Central Committee [22], and scholars discussed the implementation of policy-oriented agricultural insurance should start with fishery insurance. Yang B. (2004) first expounded the necessity of policy-oriented agricultural insurance and fishery came first from ten aspects such as industry attribute, economic basis and insurance concept [23]. However, policy-oriented agricultural insurance system is less frequently applied in reality. Sun Y.S. (2006) believed that the national agricultural insurance system had not been fully implemented for the time being, and the Ministry of Agriculture could fully play a guiding role and made a breakthrough in policy-oriented fishery insurance [24] Fan Z.A. et al. (2007) proposed that the subjective and objective conditions of fishery insurance are already in place and that the policy implementation of fishery insurance needs to be enforced [25]. From 2008 to 2010, "fishery insurance subsidy" appeared for the first time in the No. 1 document of the Central Committee. Policy agricultural insurance carried out pilot projects throughout the country to increase the varieties and regions of agricultural insurance premium subsidies [26,27]. The premium scale of China's agricultural insurance leapt to the second in the world and the first in Asia [28]. Within academic circles, the number of research on fishery insurance and policy-oriented fishery insurance peaked during this period (see Figure 1). Jin L.G. et al. (2010) believed that fishery insurance urgently needs the strong support of national laws and policies [29]. From the perspective of fishery subsidy, Duan Z.X. et al. (2010) thought that China's fishery insurance system should establish a government-supported insurance system through fiscal and tax preferential policies and reinsurance [30]. Liu T. et al. (2010) took fishing vessel insurance as an example to explore five models in the practice of fishing vessel insurance policy and believed that government support, legal protection and financial subsidy are the key to improve the fishing vessel insurance mechanism [31]. Tong C.F. et al. (2011) summarized the diversified policy models in fishery insurance, such as "collective insurance", "self-insurance", "mutual insurance" and "commercial insurance [32]". The policy model with the characteristics of public welfare is considered 
suitable for the development of fishery insurance in China. From 2004 to 2011, with the attention and guidance of the central government to agricultural insurance, fishery insurance entered a period of institutional exploration. Scholars paid attention to the necessity and feasibility of fishery insurance policy and the policy measures to improve fishery insurance system, including mutual insurance, but research focusing on policy of fishery insurance itself and its effect remains scarce.

The first agricultural insurance regulations in China's history were promulgated in 2012. Fishery mutual insurance and reinsurance policy were given key guidance $[33,34]$. Scholars found that fishery mutual insurance policy was out of balance between supply and demand, a single type of insurance, had imperfect legislation and lacked affiliated service institutions of fishery insurance $[35,36]$. Tuo G.Z. (2012) believed that the fishery mutual insurance system should be improved from many aspects, such as legal status, member participation and so on [37]. Studies on the development of fishery mutual insurance, comparison of international fishery insurance development experience, and importance of policy guidance set off the most exciting part of the research in the field of fishery mutual insurance (see Figure 1). In comparison, research in related fields abroad was more cutting-edge, and some studies focused on the evaluation of fishery insurance system or policy effect. Hong S.H. (2008) studied two insurance clauses in South Korea and found a lack of professionalism in the group mutual insurance organizations established by local governments [38]. Qian X.A. (2008) pointed out that the insurance system of fishery credit cooperatives should establish a fair premium collection and liability management system [39]. When studying the text of the fishing vessel insurance policy, Lee K.N. et al. (2013) found problems in the compensation setting of "less than 5 tons" and put forward an improvement scheme [40]. Semin P. (2017) compared the contents of the Korean fishery insurance policy and the British Association Ship Marine Insurance Time Clause (ITCHulls) and put forward suggestions on the improvement of fishery insurance policy from the aspects of policy background, estimated cost, and protection of small fishermen among others [41]. Nayani S. et al. (2018) used the combination of quantitative and qualitative analysis methods; established the four criteria of effectiveness, flexibility, political feasibility, and enforceability to score and analyze the policy content; and put forward a plan for policy improvement [42]. By contrast, up to now, most of the relevant domestic studies continue to focus on institutional ideas and measures. The policy effectiveness of fishery insurance has not been evaluated, especially the lack of quantitative conclusion support.

Since the establishment and operation of the policy-oriented agricultural insurance system in China, great changes have taken place in agricultural insurance, including fishery insurance, which has solved the problem of risk compensation for the development of modern agriculture to a certain extent [43,44]. The policy-based fishery insurance system supported by the government drives fishery insurance to develop in the direction of diversification, multi-coverage and cultivation of multiple types of insurance [45]. In 2017, the central government proposed to build a linkage mechanism of fishery insurance [46]. The design of fishery insurance products requires not only financial support but also professional cooperation between government departments and insurance companies [47]. Tuo G.Z. (2018) pointed out the changes in the insurance policy environment will promote the development of future agricultural insurance policies, including fisheries, from improving risk resistance to agricultural modernization, farmers' income, market competitiveness of agricultural product, agricultural supply side reforms and other multi-objective development $[48,49]$.

In addition to academic discussion, scholars paid attention to the practical problems in the development of fishery insurance and analyzed the development direction of the future fishery insurance policy from the practical problems. However, research on the fishery insurance policy itself is scant. The evaluation of the effect of fishery insurance policy is even less. Research of fishery insurance policy is basically based on qualitative analysis, lacking quantitative evaluation of the policy. Moreover, agricultural insurance often serves as a policy instrument through which governments regulate or intervene in 
fishery markets [50]. The formulation of fishery insurance policy needs to improve the ability of fishery disaster prevention and mitigation, improve the professional guidance ability of fishery risk, formulate accurate fishery insurance policy and get strong support from empirical evaluation. Policy evaluation has an important effect on the effectiveness of policy implementation, and it is a key link in the policy cycle. In recent years, the availability of digital policy text big data and the rapid development of text mining technology provide research opportunities and method support for the quantitative evaluation of fishery insurance policy [51-53]. China's agricultural insurance (including fishery insurance) implements the policy of multi-sector "coordinated promotion" [49], but the effect of fishery insurance policy implementation is unknown. The formulation and implementation of fishery insurance policies must be supported by research based on quantitative evaluation.

To systematically evaluate the effect of fishery insurance policy, we selected 13 closely related fishery insurance policies through text mining technology and word frequency statistics. We then performed a quantitative analysis of fishery insurance policy by using the index model of Policy Modeling Consistency (PMC) so as to provide empirical basis for the scientific formulation of fishery insurance policy. PMC index model has been popular at home and abroad in recent years.

\section{Materials and Methods}

\subsection{Policy Evaluation System of PMC Index Model}

The PMC index model is a research model to measure the internal consistency of policies. Based on the omnia mobilis (the relationship between things and movement characteristics) assumption, Ruiz Estrada et al. have proposed policy modeling by acknowledging the dynamic and complex relationships among a large number of variables $[54,55]$. PMC index model can determine the level of consistency, advantages, and disadvantages of policy models. It is suitable for any research related to economic policy, such as welfare and social policy, and it helps improve the quality of future policy modeling. Therefore, the fishery insurance policy evaluation based on PMC index model can scientifically evaluate the policy performance and analyze that the existing policies are inadequate to make further optimization.

\subsubsection{Variable Classification and Parameter Identification}

Taking fishery insurance policy as the research object, we used the research paradigm of Ruiz Estrada's policy evaluation and drew lessons from the policy tool research ideas of Yang T. et al. (2021), Kuang B. et al. (2020), Wu W.H. (2020) and Zhang Y.A. (2017) [56-59]. Nine adjusted and established first-level variables and forty-four second-level variables are listed in Table 1, including policy nature, policy effectiveness, policy type, policy function, policy limitation, policy area, incentive and restriction, policy evaluation and issuing institutions.

To construct a quantitative evaluation framework of fishery insurance policy and ensure the same importance between secondary variables, we used binary assignment. Firstly, it is clear that the policy text is related to the subject of fishery insurance, and then when the content of the policy text appears keywords corresponding to the meaning of the secondary variable, or when there are corresponding synonyms or sentences in the text, the variable assignment is objectively based on the content of the text, that is, the parameter of the secondary variable is recorded as 1 , otherwise it is 0 .

\subsubsection{Construction of Multi-Input-Output Table}

The multi-input-output table uses the database analysis framework to measure a single variable by storing a large amount of data. Each single variable can measure the evolution of any policy from a general perspective. The multi-input-output table constructed forms the quantitative evaluation system of fishery insurance policy by assigning 44 secondary variables under 9 first-level variables. 
Table 1. Evaluation index system of fishery insurance policy.

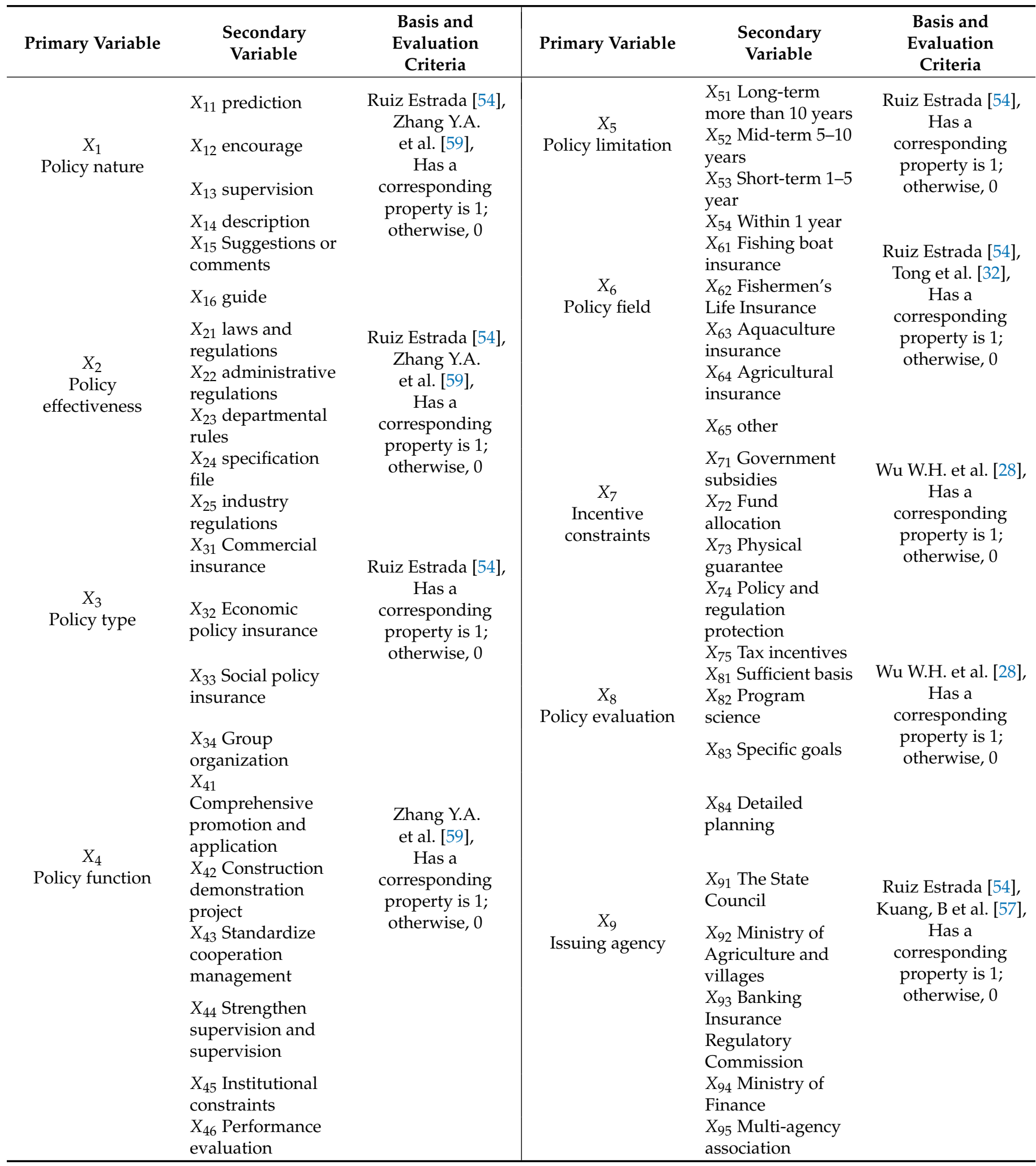




\subsubsection{PMC Index Calculation}

The PMC index can reflect the internal consistency of fishery insurance policies in different degrees. First, 9 first-level variables and 44 second-level variables are put into the multi-input-output table. Each second-level variable is assigned according to Formulas (1) and (2), and then each first-level variable is further calculated according to Formula (3). Finally, the PMC index of each fishery insurance policy is obtained by Formula (4). Among the nine primary variables, the secondary variables of $X_{5}$ are mutually exclusive, and the values of the other eight primary variables are less than or equal to 1 . Therefore, the highest score of PMC index in this paper is 8.25. According to the division standard of the PMC index method defined by Ruiz Estrada (According to the division standard of the method creator Ruiz Estrada, the first step is to obtain the maximum score of each secondary variable, that is, the maximum score $M$, according to the setting of the policy evaluation index system. The second step is to intercept the median of the data set of $[0, M]$, take the quartile as $\mathrm{m}$. $[0, m]$ belongs to the category of low consistency evaluation, and $[M-1, M]$ is classified under the category of excellent consistency evaluation. In the third step, we continued to intercept the median of $[m, M]$ and divided it into the categories of acceptable and good consistency evaluation.), the consistency evaluation of fishery insurance policy is divided into four different grades (see Table 2). If the score of the PMC index is between 0 and 4.12, the evaluation result is a low consistency policy. A score between 4.13 and 5.68 indicates acceptable consistent policy performance, a score between 5.69 and 7.24 indicates a good consistent policy, and a score between 7.25 and 8.25 indicates an excellent consistent policy. The higher the score, the wider the range of variables involved in the policy text of fishery insurance, and the more comprehensive the content of fishery insurance in the policy text.

$$
\begin{gathered}
X \sim N[0,1] \\
X \sim N\{X R:[0,1]\} \\
X_{t}\left(\sum_{j=1}^{n} \frac{X_{t j}}{T\left(X_{t j}\right)}\right)
\end{gathered}
$$

Table 2. Policy evaluation criteria based on PMC index.

\begin{tabular}{ccccc}
\hline Evaluation Criteria & \multicolumn{4}{c}{ Evaluation Result } \\
\hline PMC index Score & $0-4.12$ & $4.13-5.68$ & $5.69-7.24$ & $7.25-8.25$ \\
Evaluation Grade & low & acceptable & good & excellent \\
\hline
\end{tabular}

In Formula (3), $t$ is a first-order variable, $j$ is a second-order variable, $t=1,2,3, \ldots \ldots$

$$
P M C=\left[\begin{array}{l}
X_{1}\left(\sum_{j=1}^{6} \frac{X_{1 j}}{6}\right)+X_{2}\left(\sum_{j=1}^{5} \frac{X_{2 j}}{5}\right)+X_{3}\left(\sum_{j=1}^{4} \frac{X_{3 j}}{4}\right) \\
X_{4}\left(\sum_{j=1}^{6} \frac{X_{4 j}}{6}\right)+X_{5}\left(\sum_{j=1}^{4} \frac{X_{5 j}}{4}\right)+X_{6}\left(\sum_{j=1}^{5} \frac{X_{6 j}}{5}\right) \\
X_{7}\left(\sum_{j=1}^{5} \frac{X_{7 j}}{5}\right)+X_{8}\left(\sum_{j=1}^{4} \frac{X_{8 j}}{4}\right)+X_{9}\left(\sum_{j=1}^{5} \frac{X_{9 j}}{5}\right)
\end{array}\right]
$$

\subsubsection{PMC Surface Drawing}

PMC surface is a visual expression of PMC index matrix, which directly shows the consistency level of policy evaluation from a multi-dimensional point of view, corresponding to the score of PMC index. According to the number of research variables, we constructed 
a $3 \times 3$ matrix as given in Formula (5) and finally constructed the PMC surface of each fishery insurance policy.

$$
\text { PMC-Surface }=\left[\begin{array}{lll}
X_{1} & X_{4} & X_{7} \\
X_{2} & X_{5} & X_{8} \\
X_{3} & X_{6} & X_{9}
\end{array}\right]
$$

\subsection{Sample Selection and Data Sources}

The development of China's fishery insurance system is relatively slow, and the laws and regulations relating to fishery insurance include the Agricultural Law of the People's Republic of China (2012), the Insurance Law of the People's Republic of China (revised in 2015), and the regulations on Agricultural Insurance (revised in 2016). More targeted laws and regulations on fishery insurance have not been promulgated. To evaluate the current macro situation of China's fishery insurance policy, we chose the policy text at the level of central regulations as the research object to ensure the representativeness and reliability of the research samples. We then retrieved and obtained the original text on the official websites of ministries and commissions such as Peking University (http:/ / www.pkulaw. cn/, accessed on 20 May 2021), China Legal Resources Bank (http:/ /www.lawyee.org/, accessed on 20 May 2021), China Government Network (http:/ / www.gov.cn/, accessed on 20 May 2021), and so on. The screening criteria are as follows. First, the policy text is closely related to "fishery insurance". Second, it belongs to the level of central laws and regulations and does not include local policies. Third, the policy of locking the word frequency statistics of "fishery insurance" is not less than 3. Fourth, there is no time limit to screen all qualified policies in the resource database. Fifty-four central regulations were retrieved under the exact matching of the full text, including 6 industry regulations, 47 departmental rules and 1 inner-party regulations. Nine central regulations were retrieved under the fuzzy matching of titles, all of which were classified as departmental regulations. Furthermore, the policies whose keyword frequency statistics is not less than 3 are retained and screened item by item. Finally, 13 policies are sorted out (see Table 3 ).

Table 3. List of 13 policies related to fishery insurance.

\begin{tabular}{|c|c|c|c|c|}
\hline $\begin{array}{l}\text { Policy } \\
\text { Number }\end{array}$ & Policy Name & $\begin{array}{c}\text { Implementation } \\
\text { Time }\end{array}$ & Issued Number & Release Department \\
\hline $\mathrm{P} 1$ & $\begin{array}{l}\text { Some opinions of the State Council on } \\
\text { the Reform and Development of the } \\
\text { Insurance Industry }\end{array}$ & 15 June 2006 & $\begin{array}{l}\text { State Development } \\
\text { (2006) No. } 23\end{array}$ & $\begin{array}{l}\text { General Office of the } \\
\text { State Council }\end{array}$ \\
\hline $\mathrm{P} 2$ & $\begin{array}{l}\text { Circular of the Ministry of Agriculture } \\
\text { on further improving the work of } \\
\text { Fisheries Mutual Insurance }\end{array}$ & 29 December 2007 & $\begin{array}{l}\text { Agriculture and } \\
\text { Fisheries Development } \\
\text { (2007) No. } 41\end{array}$ & $\begin{array}{l}\text { Ministry of Agriculture } \\
\text { and villages }\end{array}$ \\
\hline P3 & $\begin{array}{l}\text { Circular of the General Office of the } \\
\text { Ministry of Agriculture on issuing the } \\
\text { 12th five-year work Plan for Fishery } \\
\text { Safety production }\end{array}$ & 11 November 2011 & $\begin{array}{c}\text { Agriculture Office } \\
\text { Fisheries (2011) No. } 113\end{array}$ & $\begin{array}{c}\text { Ministry of Agriculture } \\
\text { and villages }\end{array}$ \\
\hline $\mathrm{P} 4$ & $\begin{array}{l}\text { Notice on carrying out the } \\
\text { performance Evaluation of the pilot } \\
\text { Project of Fisheries production loss } \\
\text { Relief and Fisheries Policy Insurance } \\
\text { in } 2011\end{array}$ & 9 January 2012 & $\begin{array}{c}\text { Fisheries Bureau } \\
\text { http:/ / www.yyj.moa. } \\
\text { gov.cn/, accessed on } 20 \\
\text { May } 2021\end{array}$ & $\begin{array}{l}\text { Bureau of Fisheries } \\
\text { Administration }\end{array}$ \\
\hline P5 & $\begin{array}{l}\text { Circular of the General Office of the } \\
\text { Ministry of Agriculture on issuing the } \\
\text { 12th five-year Plan for the } \\
\text { Development of National Fisheries } \\
\text { Mutual Insurance (2012-2015) }\end{array}$ & 9 July 2012 & $\begin{array}{c}\text { Agriculture Office } \\
\text { Fisheries (2012) No. } 83\end{array}$ & $\begin{array}{l}\text { Ministry of Agriculture } \\
\text { and villages }\end{array}$ \\
\hline
\end{tabular}


Table 3. Cont.

\begin{tabular}{|c|c|c|c|c|}
\hline $\begin{array}{l}\text { Policy } \\
\text { Number }\end{array}$ & Policy Name & $\begin{array}{l}\text { Implementation } \\
\text { Time }\end{array}$ & Issued Number & Release Department \\
\hline P6 & $\begin{array}{l}\text { Circular of the General Office of the } \\
\text { Ministry of Agriculture on doing a } \\
\text { good job in the insurance of } \\
\text { ocean-going fishing vessels and crew }\end{array}$ & 23 January 2014 & $\begin{array}{c}\text { Agriculture Office } \\
\text { Fisheries (2014) No. } 8\end{array}$ & $\begin{array}{c}\text { Ministry of Agriculture } \\
\text { and villages }\end{array}$ \\
\hline P7 & $\begin{array}{c}\text { Circular of the CIRC on issuing the } \\
\text { outline of the 13th five-year Plan for } \\
\text { the Development of China's Insurance } \\
\text { Industry }\end{array}$ & 23 August 2016 & $\begin{array}{l}\text { Supervision issued } \\
\text { (2016) No. } 74\end{array}$ & $\begin{array}{l}\text { China Banking and } \\
\text { Insurance Regulatory } \\
\text { Commission (1) }\end{array}$ \\
\hline P8 & $\begin{array}{l}\text { National Agricultural Modernization } \\
\text { Plan (2016-2020) }\end{array}$ & 17 October 2016 & $\begin{array}{l}\text { State Development } \\
\text { (2016) No. } 58\end{array}$ & $\begin{array}{l}\text { General Office of the } \\
\text { State Council }\end{array}$ \\
\hline P9 & $\begin{array}{c}\text { Circular of the Ministry of Agriculture } \\
\text { on issuing the Thirteenth five-year } \\
\text { Plan for National Fisheries } \\
\text { Development }\end{array}$ & 31 December 2016 & $\begin{array}{l}\text { Agriculture and } \\
\text { Fisheries Development } \\
\text { (2016) No. } 36\end{array}$ & $\begin{array}{c}\text { Ministry of Agriculture } \\
\text { and villages }\end{array}$ \\
\hline P10 & $\begin{array}{l}\text { Circular of the Ministry of Finance on } \\
\text { the issuance of the measures for the } \\
\text { Administration of Agricultural } \\
\text { Insurance Premium subsidies of the } \\
\text { Central Finance }\end{array}$ & 1 January 2017 & $\begin{array}{l}\text { Financial (2016) } \\
\text { No. } 123\end{array}$ & Ministry of Finance \\
\hline P11 & $\begin{array}{l}\text { Circular of the Ministry of Finance, } \\
\text { the Ministry of Agriculture and } \\
\text { villages, the Banking and Insurance } \\
\text { Regulatory Commission and the } \\
\text { Forestry and Grass Bureau on issuing } \\
\text { the guidance on speeding up the } \\
\text { High-quality Development of } \\
\text { Agricultural Insurance }\end{array}$ & 19 September 2019 & $\begin{array}{l}\text { Financial (2019) } \\
\text { No. } 102\end{array}$ & $\begin{array}{c}\text { Ministry of Finance, } \\
\text { Ministry of Agriculture } \\
\text { and villages, Banking } \\
\text { and Insurance } \\
\text { Regulatory } \\
\text { Commission, National } \\
\text { Forestry and grassland } \\
\text { Bureau }\end{array}$ \\
\hline P12 & $\begin{array}{l}\text { Circular of the Ministry of Agriculture } \\
\text { and villages on issuing the "three-year } \\
\text { Action Plan for the rectification of } \\
\text { Fishery Safety production" }\end{array}$ & 15 May 2020 & $\begin{array}{l}\text { Agriculture and } \\
\text { Fisheries Development } \\
\text { (2020) No. } 11\end{array}$ & $\begin{array}{c}\text { Ministry of Agriculture } \\
\text { and villages }\end{array}$ \\
\hline P13 & $\begin{array}{l}\text { Circular of the General Office of the } \\
\text { Ministry of Agriculture and Village } \\
\text { and the General Office of the Banking } \\
\text { and Insurance Regulatory } \\
\text { Commission on promoting the Reform } \\
\text { of Fisheries Mutual Insurance system }\end{array}$ & 22 May 2020 & $\begin{array}{c}\text { Agriculture Office } \\
\text { Fisheries (2020) No. } 16\end{array}$ & $\begin{array}{l}\text { Ministry of Agriculture } \\
\text { and villages }\end{array}$ \\
\hline
\end{tabular}

(1) Bank of China Insurance Regulatory Commission (hereinafter referred to as: China Banking and Insurance Regulatory Commission or Banking Insurance Regulatory Commission).

\section{Results}

\subsection{PMC Index Score}

The results of the quantitative evaluation of fishery insurance policy based on PMC index are shown in Table 4. On the whole, the PMC index of 13 fishery insurance policies shows that three policies have good policy consistency, nine have acceptable policy consistency and one has low policy consistency. The average PMC index of 13 policies is 5.12 , and the average evaluation grade of the policy has not yet reached a good level in the acceptable range. The timeliness of the policy is relatively balanced, involving long-term and short-term planning. The performance advantage and consistency evaluation of fishery insurance policy is in the middle acceptable level, the effect of the policy is poor, the advantage in the field of fishery insurance is not prominent and the policy performance is not brought into full play. 
Table 4. Results of quantitative evaluation of fishery insurance policy based on PMC index.

\begin{tabular}{|c|c|c|c|c|c|c|c|c|c|c|c|c|}
\hline Evaluate & $X_{1}$ & $X_{2}$ & $X_{3}$ & $X_{4}$ & $X_{5}$ & $X_{6}$ & $X_{7}$ & $X_{8}$ & $X_{9}$ & & & \\
\hline Policy & Nature & Effectiveness & Type & Function & Limitation & Field & $\begin{array}{l}\text { Incentive } \\
\text { Constraints }\end{array}$ & Evaluation & Agency & PMC Index & Grade & Rank \\
\hline P1 & 0.67 & 0.60 & 0.50 & 0.67 & 0.25 & 0.40 & 0.40 & 0.75 & 0.20 & 4.43 & acceptable & 11 \\
\hline P2 & 0.67 & 0.60 & 0.50 & 0.67 & 0.25 & 0.80 & 0.20 & 0.75 & 0.20 & 4.63 & acceptable & 9 \\
\hline P3 & 0.67 & 0.60 & 0.50 & 0.67 & 0.25 & 0.60 & 0.40 & 1.00 & 0.20 & 4.88 & acceptable & 7 \\
\hline P4 & 0.50 & 0.60 & 0.75 & 0.83 & 0.25 & 0.40 & 0.40 & 0.75 & 0.20 & 4.68 & acceptable & 8 \\
\hline P5 & 0.83 & 0.60 & 0.75 & 1.00 & 0.25 & 0.80 & 0.80 & 1.00 & 0.20 & 6.23 & good & 2 \\
\hline P6 & 0.50 & 0.60 & 0.75 & 0.17 & 0.25 & 0.40 & 0.20 & 0.75 & 0.20 & 3.82 & low & 13 \\
\hline P7 & 0.67 & 0.60 & 1.00 & 1.00 & 0.25 & 0.40 & 0.60 & 0.75 & 0.20 & 5.47 & acceptable & 5 \\
\hline P8 & 0.67 & 0.60 & 0.75 & 1.00 & 0.25 & 0.40 & 1.00 & 0.75 & 0.20 & 5.62 & acceptable & 4 \\
\hline P9 & 0.67 & 0.60 & 1.00 & 1.00 & 0.25 & 0.80 & 1.00 & 1.00 & 0.20 & 6.52 & good & 1 \\
\hline P10 & 0.67 & 0.60 & 0.75 & 0.50 & 0.25 & 0.20 & 0.40 & 0.75 & 0.20 & 4.32 & acceptable & 12 \\
\hline P11 & 1.00 & 0.60 & 0.75 & 1.00 & 0.25 & 0.40 & 0.60 & 0.75 & 0.80 & 6.15 & good & 3 \\
\hline P12 & 0.67 & 0.60 & 0.50 & 1.00 & 0.25 & 0.40 & 0.80 & 0.75 & 0.20 & 5.17 & acceptable & 6 \\
\hline P13 & 0.50 & 0.60 & 0.75 & 0.33 & 0.25 & 0.60 & 0.20 & 0.75 & 0.60 & 4.58 & acceptable & 10 \\
\hline Mean & 0.67 & 0.60 & 0.71 & 0.76 & 0.25 & 0.51 & 0.54 & 0.81 & 0.28 & 5.12 & acceptable & - \\
\hline
\end{tabular}


Specifically, first, the PMC index of P9 is 6.52, ranking first and showing good policy consistency. P5 and P11 are the second and third policies in the PMC index, respectively. From the point of view of the score of the first-level variable, in terms of policy effectiveness, function and incentive and restriction, the PMC index scores of the three well-consistent policies are all higher than or equal to the average. P9 enhances the practical effect of the policy from the aspects of fishery insurance policy classification and issuing institutions. Second, the PMC index of P6 is 3.82, with the lowest score. It has little effect on guiding fishery insurance and low policy performance. The policy guidance, concreteness and comprehensiveness of $\mathrm{P} 6$ are relatively insufficient. The PMC indexes of the other nine policies (P1, P2, P3, P4, P7, P8, P10, P12, P13) are all between [4.13, 5.68]. The consistency evaluation focuses on the acceptable range, and the scores vary in policy function, policy field, incentive and restriction, policy evaluation and issuing institution. Third, the result of policy consistency evaluation has a synergistic effect on the number of papers published in fishery insurance research. Thirteen closely related fishery insurance policies are distributed between 2006 and 2020, taking into account the time lag effect. Although policy-based agricultural insurance was first proposed in 2004, academic research began to involve both policy-based fishery insurance and mutual fishery insurance (see Figure 1). However, the policy of closely related fishery insurance in the legal database began in 2006. From the perspective of policy implementation background and late fermentation, the three policies with good performance scores fluctuated synchronously with academic fishery insurance research after their implementation in 2012, 2016 and 2019 (see Figure 1). At the implementation stage of P5 in 2012, the volume of fishery mutual insurance reached its peak for the first time. After the implementation of P9 at the end of 2016, the research on fishery insurance and fishery mutual insurance fluctuated upward, along with the implementation of P11 in 2019. The research on fishery insurance and policy fishery insurance rose synchronously and then ushered in the second small peak of fishery mutual insurance research in the second year. During the implementation of P6, which has the lowest policy consistency, the research on fishery insurance is in the "trough" stage. Fourth, in terms of the content dimensions involved in the policy, the existing fishery insurance policies are mainly economic policy insurance. Each policy involves financial subsidies, and fishery mutual insurance accounts for a large proportion. Most of the policies for commercial insurance appear in the form of encouragement, but the maneuverability is weak. Thirteen fishery insurance policies do not involve laws and regulations, and the issuing departments are concentrated in specific single institutions.

\subsection{PMC Surface Comparison}

According to the PMC index results of 13 fishery insurance policies, we constructed 13 PMC matrices, brought each policy into $3 \times 3$ matrix, drew the PMC surface of fishery insurance policies, and measured the consistency level of fishery insurance policies in 3D space. Limited by space, Figure 2 shows only the surfaces with the lowest and highest policy scores to highlight the effect of comparison. In the figure, 1, 2 and 3 represent the horizontal coordinate values of the matrix, series 1,2 and 3 represent the ordinate values of the matrix and spatial coordinates represent the score of the policy in each dimension. Each color block represents the score category of different dimensions, and the degree of concavity and convexity of PMC surface can measure the consistency of fishery insurance policy. The concave surface of the curved surface indicates that the score of the policy in the corresponding evaluation dimension is lower, whereas the convex surface indicates that the policy has a higher score in the corresponding evaluation dimension. When the surface is relatively smooth in space and located in the upper region of the triad, the evaluation of each dimension of the policy is better, and the level of consistency is higher, which is the ideal policy standard.

As shown in Figure 2, comparing the PMC surface of the fishery insurance policy with the lowest and highest scores, on the whole, the surface maps of P6 and P9 are significantly different. The spatial coordinates of the surface of P6 are small, and most of the surfaces are 
located in the lower part of the space. A large area of low-score color blocks appeared on the surface, which more intuitively shows that P6 has a lower score in many dimensions. The surface of P9 with the highest score tends to "overflow" in the spatial position. Except for two obvious low-dimensional depressions, the other dimensions are in the upper part of the space, and the overall score is higher. Affected by individual dimensions, the performance score of P9 is good, but it still needs to be improved. The concavity and convexity of the policy consistency surface reflects the urgent need for fishery insurance policies that are targeted and can highlight multi-dimensional effectiveness.

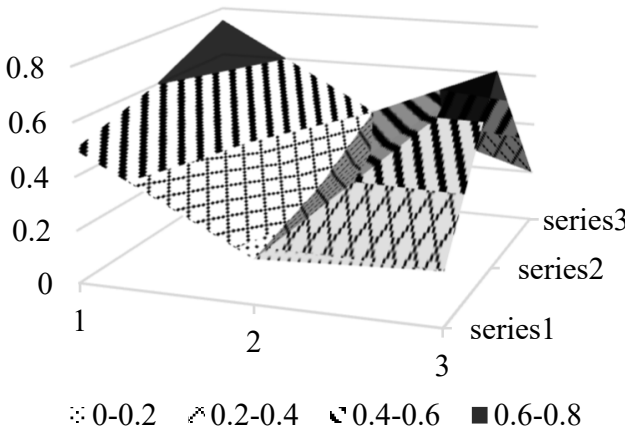

(a) PMC surface of policy P6

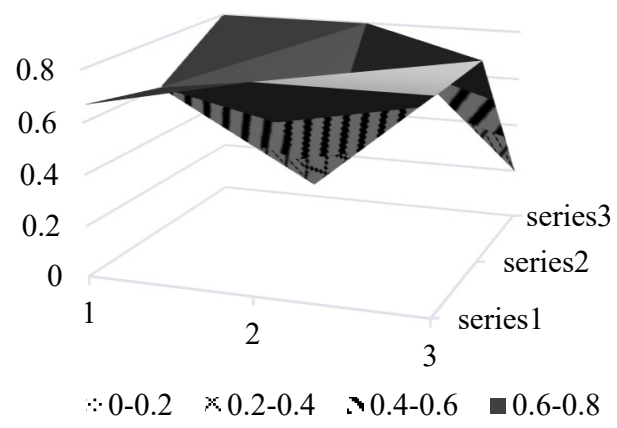

(b) PMC surface of policy P9

Figure 2. PMC surface of fishery insurance policy.

\subsection{Comparison of Different Policy Dimensions}

Policy consistency evaluation evaluates the performance, advantages, and disadvantages of policies from multiple dimensions. To highlight the subdivision differences in each dimension clearly, the two policies with the lowest (P6) and highest PMC index score (P9) among the 13 fishery insurance policies are further subdivided and compared. P6 is mainly aimed at the insurance work of the offshore fishery. Owing to the high-risk characteristics of the offshore fishing industry, the incidence of production safety accidents in the oceangoing industry is relatively high. The purpose of this policy is to urge offshore fishing enterprises to provide offshore fishing insurance for fishing vessels and crew. P9 is in the decisive period of building a well-off society in a holistic way. To vigorously promote the supply side structural reform of fisheries and in accordance with the overall requirements of the 13th Five-year Plan for National Economic and Social Development of the People's Republic of China and the National Agricultural Modernization Plan (2016-2020), the five-year plan was formulated according to the actual situation of the fishery. Figure 3 shows the difference between P6 and P9 and the mean at each level of variables. The two policies score the same in terms of $X_{2}$ (policy effectiveness), $X_{5}$ (policy limitation) and $X_{9}$ (issuing agency), but score below average in $X_{9}$.

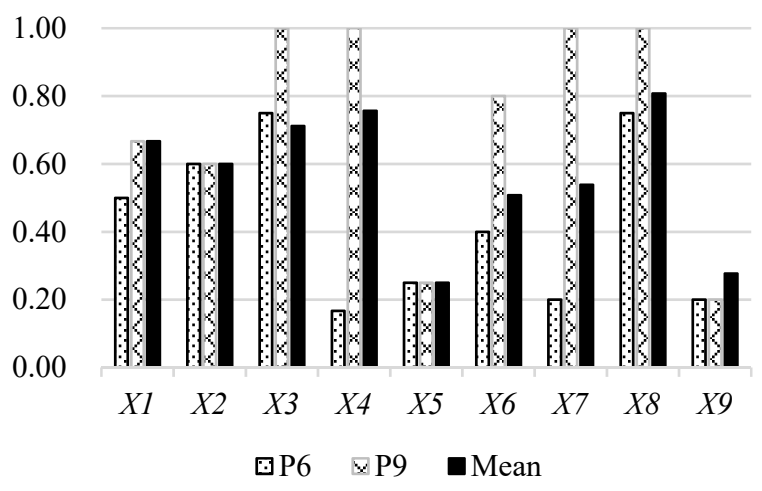

Figure 3. Comparison of policies P6 and P9. 
Comparing the gap between the dimensions of P6 and P9, policy nature $\left(X_{1}\right)$ and policy type $\left(X_{3}\right)$ are limited by their own starting point and positioning. The scope of attribution should be divided according to the original intention of the issuing institution. Policy evaluation $\left(X_{8}\right)$ needs to comprehensively consider other dimensions before scoring. According to the results of the policy multi-dimensional evaluation shown in Figure 4, we compared P6 and P9 from four aspects: $X_{4}$ (policy function), $X_{6}$ (policy field), $X_{7}$ (incentive constraints) and $X_{9}$ (issuing agency).

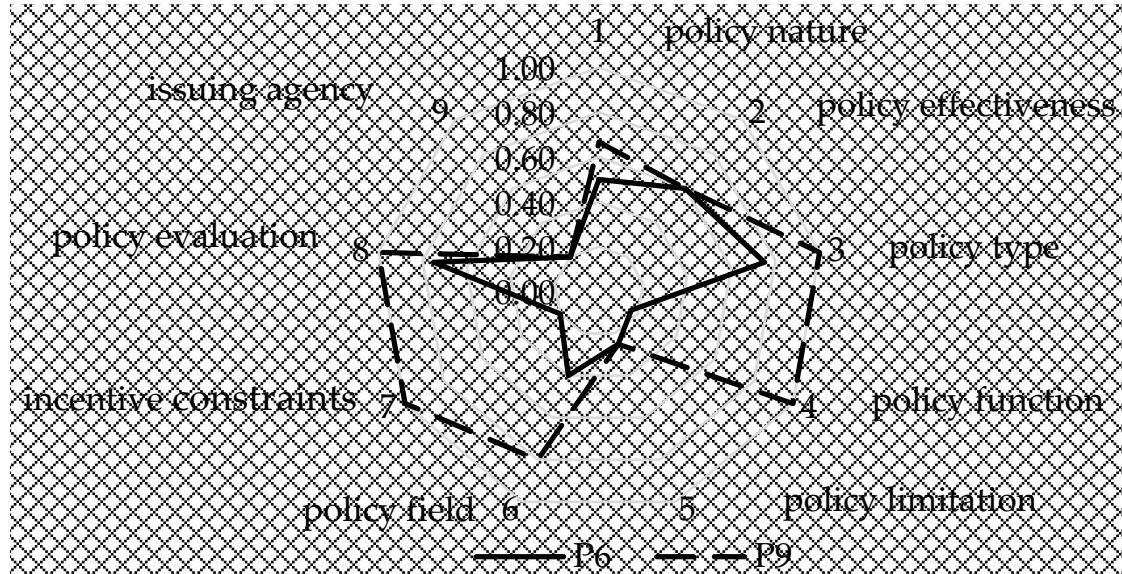

Figure 4. Comparison of multi-dimensional evaluation of policies P6 and P9.

1. Compared with P6, P9 focuses more on the future development strategy and construction planning of fishery insurance, locking the scope of guidance and coming up with more targeted guidance can give full play to the function of the policy. The implementation of fishery insurance policy can be summarized into six aspects: promotion and application, construction of demonstration projects, standardization of cooperative management (fishery mutual insurance association, etc.), supervision, institutional restraint and performance evaluation. Implemented in 2014, P6 mainly encourages and guides the application of fishery insurance in offshore undertakings and supports the services of fishery mutual insurance to offshore fisheries. P6 focuses on the insurance work of the offshore fishing industry, and its policy functions and priorities are limited by its own starting point. There is only one place to "strengthen the publicity and promotion of fishery insurance knowledge" in the document, so the score is relatively low. Implemented in 2016, P9 focuses on the five-year plan for fishery development. Although P9 is not a policy for fishery insurance, it focuses on short-term planning for fishery development with relatively more detailed contents. Among the documents, 26 are related to fishery promotion and application, 32, construction and demonstration projects, 12, cooperative management, 25, system construction, 20, fisheries regulation and 1, assessment of fisheries law enforcement.

2. P9 contains the classification of fishery insurance field more comprehensively than P6. The fishery insurance policy considering the whole subset classification can balance the weight of each dimension and evaluate the policy consistency scientifically. Fishery insurance belongs to agricultural insurance in a broad sense, which generally involves fishing vessel insurance, fishermen's life insurance, and aquaculture insurance. P6 only mentions the life insurance of fishing vessels and fishermen and does not fully take into account the comprehensiveness of the sub-classification in the guidance of fishery insurance. Although P9 involves the relevant contents of aquaculture insurance, there is only one brief reference to "actively carrying out insurance for aquaculture, fishing vessels, and fishermen, and a sound and stable fishery risk protection system". The specific operation of the implementation of fishery insurance policy is not involved. 
3. P9 involves a series of incentive or restriction means, which greatly reduces the dependence on government financial subsidies and maintains the long-term sustainability of policy implementation compared with P6. Subsidy is a common means of government incentive mechanism. Except for P13, all other policies are related to financial subsidies. P6 actively advocates "bringing offshore fishery insurance into the scope of local financial subsidies and giving full play to the advantages of policy insurance". In fishery mutual insurance, P6 also advocates to give full play to the advantages and role of policy insurance, but there is a lack of other incentives and restrictions. Blindly emphasizing government subsidies will not only cause a huge financial burden but is also not conducive to the development of a variety of incentives and constraints. Doing so cannot give full play to the comprehensive advantages of multiple linkages. P9 comprehensively takes into account the incentives and constraints of government subsidies, taxation, investment and the legal system and makes a wealth of policy guidance.

4. Both P6 and P9 have two similar problems, that is, the issuing organization is single, and the advantage of specialization is not prominent. Fishery insurance is a financial product derived from the two cross industries of fishery and insurance. The planning and management of fishery insurance require not only professional fishery experts but also professional assessment of insurance inspection and loss. P6 and P9 are issued by the Ministry of Agriculture and villages (formerly the Ministry of Agriculture), and there is no multi-agency professional cooperation. The agricultural insurance policy (P11), which was jointly issued by the Ministry of Finance, the Ministry of Agriculture and Village, the Banking and Insurance Regulatory Commission and the Forestry and Grass Bureau, scores the highest in $X_{9}$. The higher the administrative level in the issuing organization, the stronger the policy strength and macro guidance [60]. The more professional cooperation among institutions, the stronger the inclusiveness and maneuverability of policy implementation. Fishery insurance belongs to crossdomain products. To excel in the planning and management of fishery insurance, the effect of professional combination of institutions must be given full play so as to ensure the professionalism, guidance and feasibility of the policy content.

The order of policy improvement is judged by the absolute value of the lower-thanaverage PMC index, and priority is given to the improvement scheme with greater absolute value. Comparing and analyzing policies $\mathrm{P} 6$ and $\mathrm{P} 9$ is beneficial to improve and enhance the consistency evaluation results of policy P6. According to the analysis of the results of the multi-dimensional score of policy $\mathrm{P} 6$, in accordance with the principle of the starting point of the policy, the suggested improvement order of $\mathrm{P} 6$ is $X_{4}, X_{7}, X_{6}$ and $X_{9}$. Improving the function and application of policies should not simply stay at the level of encouragement, guidance and description. Only by promoting the landing of the project, standardizing the cooperation and management of policy implementation and doing a good job of feedback and performance appraisal in time can the effectiveness of the policy be improved before, during and after the event. Various forms of incentives and restrictions should be considered to give full play to the effectiveness of the policy. Blindly emphasizing the intensity of subsidies can only increase the financial burden of the government. Diversified cooperation is more conducive to improving the efficiency of implementation. In addition, the more detailed and specific the policy is, the higher the requirements for professional knowledge and accurate matching. Advocating cooperation between departments and introducing professional technical teams to optimize the allocation of resources can promote policy implementation more effectively. The "low", "acceptable", "good" and "excellent" obtained from the evaluation results of policy consistency reflects the comprehensiveness of the current policy, which is conducive to helping the fishery insurance policy implement the improvement path and raise the level of policy guidance. 


\section{Research Conclusions and Policy Inspiration}

\subsection{Conclusions}

With text mining technology as a basis, we combed the evolution of fishery insurance policy and its academic research trends. The conclusion shows that achieving sustainable development by relying solely on the fishery insurance of commercial institutions is difficult. During the 40 years of the development of fishery insurance, the business subjects underwent three adjustments of commercial organizations, mutual insurance associations and professional insurance institutions in turn. The fishery insurance policy has gradually matured from initial attention to change and development. Policy fishery insurance became the most important form of fishery insurance at present. Thirteen closely related fishery insurance policies are quantitatively analyzed by using PMC index model, and the main conclusions are as follows.

First, in the PMC index score of 13 fishery insurance policies, no policy has excellent policy consistency: 3, good; 9 , acceptable; 1 , low. The average result of fishery insurance policy consistency evaluation is at an acceptable level, but the guiding effect of the policy on the field of fishery insurance is not comprehensive. There is still room for improvement in the guiding effect of the current fishery insurance policy at the level of central laws and regulations. Considering that the advantages in the field of fishery insurance are not prominent, weak links in the formulation of fishery insurance policies need to be improved.

Second, the result of policy consistency evaluation has a synergistic effect on the number of papers published in fishery insurance research. The practical effect of highquality fishery insurance policy is helpful to guide the theoretical research of fishery insurance and promote the healthy development of fishery insurance.

Third, the existing fishery insurance policy has four problems. First, the main body of policy release is single. With lack of professional division of labor guidance, forming a joint force between departments is difficult. Among the 13 policy documents selected, all 12 policies were promulgated by a single agency, and only 1 policy was jointly issued by multiple agencies. This policy jointly issued by multi departments obtained relatively good index scores in the policy modeling consistency evaluation. Only based on the research scope and characteristics of this manuscript, the research highlights the advantages of cooperation and linkage among multiple departments. Of course, we also need to consider the pros and cons of dual resilience of multi-agency joint policies. Second, the policy function and field are limited, and subdivision guidance is lacking in the field of fishery insurance. The policy does not give full play to its traction role in policy promotion, demonstration construction, supervision and management, performance feedback and so on. The classification of fishery insurance, especially the planning guidelines represented by aquaculture insurance, is also not detailed. Third, the incentive and restriction mean of fishery insurance policy rely on financial subsidies, and the maneuverability of commercial insurance and other forms of participation is low. As a result, maintaining the longterm sustainability of policy implementation is challenging. Finally, more targeted and comprehensive laws and regulations are lacking in the development of fishery insurance, and the protection system needs to be improved.

\subsection{Policy Inspiration}

According to the four main problems in the field of fishery insurance policy found in the previous studies, we come up with the following insights:

1. Strengthen multi-sector cooperation and highlight policy professionalism. Limited to the characteristics of fishery, the development of fishery insurance needs to rely on the strength of the government, and many government departments are often involved in the fishery insurance policy. The 13 policies involve the State Council, the Ministry of Agriculture and Village, the Bancassurance Regulatory Commission, the Ministry of Finance and the State Forestry, as well as Grassland Administration. In the actual participation of multiple sectors, directional cooperation and guidance should be carried out according to the characteristics of departments. Only through formulation 
and implementation of fishery insurance policies can the advantages of professional and cooperative cooperation be brought into full play. The quality and guiding effect of fishery insurance policies should be improved. In terms of policy function and category guidance, the Ministry of Agriculture and Village, as the main responsible body for the implementation of fishery insurance policy, plans the policy direction in terms of macro strategy and plays a leading role in the publicity and promotion of fishery insurance policy. The Ministry of Finance and the Ministry of Ecological Environment can evaluate the promotion of fishery insurance projects in terms of funds and environment. The Emergency Management Department, Meteorological Bureau and Market Regulatory Administration can give full play to the advantages of specialized departments. Fishery risk assessment and supervision and management in the policies should be guided scientifically. As another important subject of fishery insurance, Banco Insurance Regulatory Commission ensures the standardized classification and professional guidance of relevant fishery insurance in the policy. In the aspect of policy playing the role of incentive and restriction, the division of labor and cooperation among multiple sectors is conducive to enriching the incentive and restriction mode of fishery insurance in the policy. The Ministry of Agriculture and Village and the Ministry of Finance play an important role in policy subsidy standards, funds, and tax systems. The Ministry of Justice provides professional legal support and protection. The Ministry of Emergency Management, the Ministry of Transport, the Market Regulatory Administration and the Bancassurance Regulatory Commission can play an important role in fishery risk assessment, physical protection such as fishing vessels and market supervision. In the aspect of improving the fishery insurance protection system, under the background of the legal protection led by the Ministry of Justice, various departments cooperate with the guidance level of other departments to improve the laws and regulations of fishery insurance so as to lay a legal foundation for further improving the fishery insurance protection system.

2. Subdivide the domain and strengthen the function and classification of the policy. Strengthening the policy function and subdividing the fishery insurance field are beneficial to the comprehensive and multi-dimensional guidance of the policy. Each policy has at least one function to achieve policy goals. The functional features involved in fishery insurance policies include promotion and application, constructing demonstration projects, advocating cooperative management, strengthening supervision and management, setting institutional constraints and so on. To improve the performance and advantages of the policy, its effectiveness should be given full play from multiple dimensions. First, the policy must lock in the market demand for fishery insurance and implement it in place, so as to encourage stakeholders to share their experiences in the way of cases and ultimately achieve the effect of policy promotion and publicity. Second, pilot projects for construction of fishery insurance demonstration projects are conductive to radiation and promotion of the implementation of fishery insurance policies in other regions. Third, the policy should guide and coordinate the interactive relationship among fishing enterprises, fishermen, fishery groups and mutual insurance institutions and then strengthen the supervision and restraint of the policy with the help of the coercive and deterrent force of the government. The latter is conducive to improving the fishery insurance system. Finally, we can establish the performance evaluation standards of the policy, improve the assessment of the promulgation, implementation and implementation of the policy and ensure the functionality of the policy. Moreover, giving full play to the effectiveness of the policy is not a general description. The subdivision planning in the field of fishery insurance must be executed well. Fishery insurance is generally divided into insurance for fishermen according to personal insurance, insurance for fishing vessels, fishing gear and other means of production according to the means of production, insurance for aquaculture and fishing according to the insurance of production activities and weather index insurance. Giving full play to the functional effectiveness of the policy 
in the specific and micro field of fishery insurance is helpful to enhance the guidance and feasibility of the policy.

3. Enrich the means of incentive and restriction and improve the maneuverability of the policy. Incentive and restriction in the policy are important means to ensure the implementation of the policy and effective achievement of the policy objectives. The incentive and restriction means should prescribe the right remedy to the case according to the problems to be solved to achieve the policy objectives. Diversified incentive and restriction means can reduce the burden caused by relying solely on government subsidies. The incentive and restriction methods should be comprehensively considered from three aspects: fishermen, aquatic products and fishery. In terms of fishermen's income, it is necessary to implement different means of financial subsidies and broaden the forms of subsidies, such as subsidy compensation, award compensation, risk compensation and reinsurance subsidy among others. To improve the efficiency of the use of financial funds, the allocation of funds should implement the principle of flexibility according to the level of fishery risk protection and the income level of insured fishermen. The higher the level of protection, the smaller the amount of premium and capital allocation. Therefore, implement a tilting premium subsidy and fund allocation mechanism for low-income fishermen are necessary. In terms of the price of aquatic products, the tax gradient should be set according to the classification and risk level of aquatic products. The proportion and object of tax collection must be adjected. The price of aquatic products should be appropriately reduced and exempted to stabilize the price market of aquatic products and ensure the feasibility of financial support. Regarding the development of fishery industry, owing to the high risk of fishery and the characteristics of decentralized management of small farmers, fishing vessels, fishing gear and other means of production often lack a standardized screening mechanism. This is not conducive to fishery production activities or even potentially enhancing fishery risks. Policy guidance can be avoided from two aspects: physical guarantee and political and legal protection. Appropriate replenishment of means of production and punitive measures with coercive and deterrent force can promote the upgrading of means of production in fishery. The reward and punishment mechanism also improves the standard of the use of means of production, which is advantageous to improving the quality of fishery development. Multi-effect means to ensure the implementation of policy objectives can effectively give full play to the guiding role of fishery insurance policy in solving the problems of agriculture, rural areas and farmers, and enhance the feasibility of policy landing.

4. Improve the fishery insurance system to ensure the feasibility of the policy. The protection system of fishery insurance should strengthen the top-level design and system planning. Legal protection is a necessary condition for the orderly and standardized development of fishery insurance and formulation of practical and effective policies. In the aspect of top-level design, to ensure the overall planning and coordination of the development of fishery insurance, multi-sector cooperation should not be based solely on the perspective of individual sector management in formulating policies and rules. A unified background of laws and regulations should be established. The government's protection objectives, scope of influence, level of support, institutional setup, and mode of operation of fishery insurance must be clarified in a legal manner. There is a law to organize and coordinate the specialized agencies involved in fishery insurance for further systematic planning. The guidance of the policy to fishery insurance should not only highlight the professionalism but also enrich the ways of protection to alleviate the upward pressure brought by fishery risks. Therefore, the triple guarantee of fishery insurance must be constructed on the basis of the background of legislative regulations. First, the professional policy guarantee is established based on the division of labor and cooperation of multiple departments, and the professional appraisal organization led by the government is responsible for calibration of insurance, loss determination of claims, and professional evaluation 
of the industry. The first layer of protection improves the level of specialization in fishery insurance policy making. Second, establish a corporate protection that can effectively give full play to the dual mechanism of the government and the market. The fishery mutual insurance association and other community organizations or associations should undertake the related affairs of fishery production assessment and mutual insurance. The second layer of protection is a feasible mechanism to stabilize the fishery insurance policy. Finally, the commercial guarantee in the market mechanism should be given full play, jointly with commercial insurance institutions, to evaluate the fishery management system and develop fishery insurance types and finally form a guarantee mechanism of triple joint prevention and control. Doing so can promote the long-term sustainability of the implementation of fishery insurance policies, improve the quality of fishery insurance policies and enhance policy guidance and effectiveness.

\section{Research Prospects}

This paper uses the visual data processing method to sort out the practical evolution and academic research development of fishery insurance. It finds that few studies based on the fishery insurance policy explore the effect of the policy. However, only by scientifically evaluating the effect of fishery insurance policy can the direction of policy optimization in the future be grasped. On this basis, we excavated the policy text and used the PMC index model to scientifically evaluate the fishery insurance policy to seek the optimization direction of policy development. Restricted by the infinity of policy evaluation dimensions and the limitation of screening criteria, this paper still has room for improvements. First, limited by space, time and energy, we only formulated nine first-level variable indicators and selected 13 policies based on keywords, which may not fully reflect the policy effect. The fishery insurance policy can be further subdivided from multiple dimensions in the future, and the sample size can be appropriately expanded according to the regulation and control field of fishery insurance policy. Second, we only performed a quantitative evaluation of the scientificalness and rationality of the content of the fishery insurance policy, reflecting the effect, advantages and disadvantages of the fishery insurance policy. However, we could not make an all-round analysis of the use and effectiveness of the fishery insurance policy only through the content of the policy text. A further empirical study on the implementation process and performance evaluation model of the policy can be carried out in the future. Finally, the design of future fishery insurance policy can be developed toward specialization. The balance mechanism among policy subjects, commercial insurance institutions, social organizations and professional and technical institutions can be explored in coordination with third-party professional institutions.

Author Contributions: Conceptualization: X.W., Q.H. Methodology: X.W. Validation: X.W., Q.H. and J.M. Draft Writing, Review and Editing: X.W., Q.H. and J.M. All authors have read and agreed to the published version of the manuscript.

Funding: This research was funded by Major Projects of Social Planning in Zhejiang Province (No. 19XXJC02ZD), the general program of Chinese National Natural Science Foundation (No. 71874092), and key projects of the National Social Science Foundation (No. 19AZD004).

Data Availability Statement: Data available in a publicly accessible repository. The data presented in this study are openly available in [Peking University] at [http://www.pkulaw.cn/], [China Legal Resources Bank] at [http:/ /www.lawyee.org/], [China Government Network] at [http://www.gov.cn/]

Acknowledgments: We appreciated all the subjects for giving their consent to participate in this project. The authors gratefully thank the editor and anonymous reviewer for their review. Looking forward to your reply.

Conflicts of Interest: The authors declare no conflict of interest. 


\section{References}

1. Li, Y.Y. The predicament and Breakthrough path of the Reconstruction of Agricultural Insurance legislation Mode in China. Stud. Law Bus. 2017, 34, 45-54.

2. Zheng, W.L.; Luo, B.L.; Zhong, W.J. Farmers' Perception of Climate Risk, Intervention of Policy Instruments and the Distortion of Agricultural Insurance Market. J. Guangdong Univ. Financ. Econ. 2020, 35, 101-111.

3. Yan, J.J.; Wu, X.M.; Qiu, J. NIFD Quarterly Bulletin (Insurance Operation): Agricultural Insurance Serves Rural Revitalization: Opportunities, Challenges and Strategic Measures; National Laboratory of Finance and Development: Beijing, China, 2021; pp. 1-7.

4. Li, J. The nature, legislative principles and development ideas of agricultural insurance. Chin. Rural Econ. 1996, 1, 55-59.

5. Ye, Z.H. Thoughts on perfecting the Agricultural Insurance system in China. J. Financ. Res. 2018, 12, $174-188$.

6. Fu, X.P.; Liang, P. Has the pilot project of policy-oriented agricultural insurance changed farmers' diversified planting behavior? J. Agrotech. Econ. 2017, 9, 66-79.

7. Circular of the General Office of the Ministry of Agriculture and Villages, the General Office of the China Banking and Insurance Regulatory Commission on promoting the Reform of Fisheries Mutual Insurance System. Available online: http:/ / www.moa. gov.cn/nybgb/2020/202007/202008/t20200811_6350176.htm (accessed on 5 May 2021).

8. Zheng, H.; Shang, M.; Zhao, X. Chinese Policy on Fishery Insurance: Evolution, Characteristics and Challenges. Mar. Policy 2020, 119, 104099. [CrossRef]

9. Jiang, M.Z.; Faure, M. Risk-Sharing in the Context of Fishery Mutual Insurance: Learning from China. Mar. Policy 2020, 121, 104191. [CrossRef]

10. Circular of the Ministry of Communications, the Ministry of Agriculture, Animal Husbandry and Fishery, the State Economic Commission, the State Administration for Industry and Commerce, the Ministry of Public Security, the People's Insurance Company of China, the Ministry of Finance, and the National Tourism Administration on Strengthening the Supervision and Administration of Ship Safety in Townships. [EB/OL].1987-03-09[2020-09-03]. Available online: https://xxgk.mot.gov.cn/2020 /jigou/bgt/202006/t20200623_3307199.html (accessed on 3 September 2021).

11. Zhao, G.H. Effect and practice of Fishery Insurance in Shatian Township. Curr. Fish. 1986, 3, $29-30$.

12. Ge, G.H. The present situation and Development Prospect of Fishery Insurance in China. Chin. Fish. Econ. 1997, 6, $22-24$.

13. Li, J. Some suggestions on the Development of Fishery Finance in China. Chin. Fish. Econ. 2001, 3, 8-9.

14. Sun, Y.S.; Li, D.X. Fishing vessel Insurance system in Japan and South Korea and its Enlightenment to China. Chin. Fish. Econ. 2003, 1, 47-49.

15. Roughgarden, J.; Smith, F. Why Fisheries Collapse and What to Do about It. Proc. Natl. Acad. Sci. USA 1996, 93, 5078-5083. [CrossRef]

16. Attwood, C.G.; Harris, J.M.; Williams, A.J. International Experience of Marine Protected Areas and Their Relevance to South Africa. Afr. J. Mar. Sci. 1997, 18, 311-332. [CrossRef]

17. Guenette, S.; Lauck, T.; Clark, C. Marine Reserves: From Beverton and Holt to the Present. Rev. Fish. Biol. Fish. 1998, 8, 251-272. [CrossRef]

18. Murray, S.N.; Ambrose, R.F.; Bohnsack, J.A.; Botsford, L.W.; Carr, M.H.; Davis, G.E.; Dayton, P.K.; Gotshall, D.; Gunderson, D.R.; Hixon, M.A.; et al. No-Take Reserve Networks: Sustaining Fishery Populations and Marine Ecosystems. Fisheries 1999, $24,11-25$. [CrossRef]

19. Lian, X.C.; Zhang, S.F. Investigation on Fisheries Mutual Insurance in Ningbo. Chin. Fish. Econ. 2003, 5, 29-30.

20. Kong, Q.Y. Proposal on requiring the establishment of a state-supported fishery insurance system for fishery mutual insurance legislation. China Fish. 2002, 4, 78-79.

21. Jin, L.G.; Li, J. The Conception of establishing a State-supported Fishery Insurance system. Chin. Fish. Econ. 2003, 6, 35-37.

22. Opinions of the CPC Central Committee and the State Council on Several Policies to Increase Farmers' Income. Available online: http://www.moa.gov.cn/ztzl/yhwj/wjhg/201202/t20120214_2481181.htm (accessed on 20 May 2021).

23. Yang, B. Discussion on giving priority to Fisheries in Policy-oriented Agricultural Insurance. Chin. Fish. Econ. 2004, 2, 27-29.

24. Sun, Y.S. On the risk of fishing vessel crew and Fishery Insurance. Chin. Fish. Econ. 2006, 2, 59-63.

25. Fan, Z.A.; Liu, F.R. Study on the Development Policy of Fishery Insurance in China. Chin. Fish. Econ. $2007,4,35-37$.

26. Some Opinions of the CPC Central Committee and the State Council on Promoting the Stable Development of Agriculture and Continuously Increasing Farmers' Income in 2009. Available online: http:/ /www.moa.gov.cn/ztzl/yhwj/wjhg/201202/t2012021 5_2481459.htm (accessed on 20 May 2021).

27. Some Opinions of the CPC Central Committee and the State Council on Strengthening the Overall Planning of Urban and Rural Development and Further Tamping the Foundation of Agricultural and Rural Development. Available online: http: / /www.moa.gov.cn/ztzl/yhwj/wjhg/201202/t20120215_2481486.htm (accessed on 20 May 2021).

28. Zeng, Y.Z.; Mu, Y.Y. Development Evaluation of China's Policy-Oriented Agricultural Insurance: Based on the Realization Degree of Policy Objectives. Agric. Agric. Sci. Procedia 2010, 1, 262-270. [CrossRef]

29. Jin, L.G.; Yang, Y.C. Analysis of policy fishery insurance in China. Guangdong Agric. Sci. 2010, 37, 309-311.

30. Duan, Z.X.; Bi, J.G. Exploration on Fishery subsidy Policy and its Reform in China. Ecol. Econ. 2010, 2, $203-207$.

31. Liu, T.; Ping, Y. Thinking and policy analysis of policy fishery insurance model in China-taking small and medium-sized fishing vessel insurance as an example. Jiangsu Agric. Sci. 2010, 2, 405-408. 
32. Tong, C.F.; Li, J. The necessity and Feasibility of implementing Policy-oriented Fisheries Insurance system. J. Univ. Financ. Econ. 2011, 24, 47-50.

33. State Council. Agricultural Insurance Regulations. Available online: http://www.gov.cn/zwgk/2012-11/16/content_2268392. htm (accessed on 20 May 2021).

34. Some Opinions of the CPC Central Committee and the State Council on Accelerating Agricultural Science and Technology Innovation and Continuously Enhancing the Supply Guarantee Capacity of Agricultural Products. Available online: Http: / /www.moa.gov.cn/ztzl/yhwj/zywj/201202/t20120215_2481552.htm (accessed on 20 May 2021).

35. Wan, J. Analysis on the problems and countermeasures of fishery mutual insurance in China. China Fish. Econ. 2012, 30, 18-22.

36. Cheng, B.Q.; Zhang, H.L. A comparative analysis of the development experience of Chinese and international fishery insurancetaking Japan, South Korea and France as examples. Pract. Foreign Econ. Relat. Trade 2012, 9, 84-87.

37. Tuo, G.Z. On China's fishery mutual insurance system and its improvement and development. J. Insur. Prof. Coll. 2012, $26,5-11$.

38. Hong, S.H. Some Considerations on the Regulations on Mutual Aid for Local Government Vessels. Marit. Law Rev. 2008, 20, 151-204.

39. Qian, X.A. Rethinking the Deposit Insurance System for Credit Cooperatives in Korea. Korean J. Coop. Stud. 2008, $26,113-145$.

40. Lee, K.N.; Zheng, Z.H. Plan for Countermeasure and Prospect of Demand and Supply About Seamen in Korea. J. Fish. Bus. Adm. 2013, 44, 47-60. [CrossRef]

41. Semin, P. A Comparative Legal Analysis on the Collision Clauses of Ships between Fishery Insurance Policy and 1983 Itc (Hulls). J. Korea Marit. Law Assoc. 2017, 39, 183-221.

42. Nayani, S.; Warlick, A. Implementation Challenges for Quota Set-Asides: Policy Analysis to Inform Fisheries Management Decision-Making. Coast. Manag. 2018, 46, 636-653. [CrossRef]

43. Tuo, G.Z. On the responsibility and power of local government in agricultural insurance. Rural Financ. Res. 2021, 3, 12-17.

44. Xu, T.T.; Rong, X. Forty years of reform and opening up: The change and innovation of China's agricultural insurance systemHistorical process, achievements and experience. Issues Agric. Econ. 2018, 12, 38-50.

45. Tuo, G.Z. On the limited competition in agricultural insurance market. Insur. Stud. 2017, 2, 11-16.

46. Some Opinions of the CPC Central Committee and the State Council on Implementing the New Concept of Development and Speeding up Agricultural Modernization to Achieve the Goal of a Well-Off Society. Available online: http:/ /www.moa.gov.cn/ ztzl/2016zyyhwj/2016zyyhwj/201601/t20160129_5002063.htm (accessed on 20 May 2021).

47. Chen, S.W.; Wang, X.L.; Niu, H. Study on the design of mariculture fishery insurance products with rainfall index. Econ. Probl. 2017, 6, 56-59.

48. Tuo, G.Z.; Zhang, Q. On the policy goal of agricultural insurance in our country. Insur. Stud. 2018, 7, 7-15.

49. Tuo, G.Z. Analysis of China's agricultural insurance policy and its possible trend. Insur. Stud. 2019, 1, 3-14.

50. Michael, R.C.; Peter, D.L.; Tewodaj, M.; Workneh, N. Poverty Traps and Natural Disasters in Ethiopia and Honduras-ScienceDirect. World Dev. 2007, 35, 835-856.

51. Zhu, X.M.; Yu, X.; Lu, H.Y. Research on the Evolution of China's Standardization Policy: Based on text quantitative Analysis. Manag. Sci. Res. 2019, 40, 12-21.

52. Liu, H.Q.; Liang, Y.C. The influence mechanism of policy content reproduction-Based on the research of agriculture-related policy text. Sociol. Stud. 2021, 36, 115-136.

53. Li, M.F.; Yang, C. Research on the selection of policy tools for the reform of real estate registration. China Land Sci. 2021, 35, 12-19.

54. Ruiz Estrada, M.A. PMC-Policy Modeling: Definition, Classification and Evaluation. J. Pol. Model. 2011, 33, 523-536. [CrossRef]

55. Ruiz Estrada, M.; Yap, S.F.; Nagaraj, S. Beyond the ceteris paribus assumption: Modeling demand and supply assuming omnia mobilis. Inter. J. Econ. Res. 2008, 5, 185-194.

56. Yang, T.; Xing, C.; Li, X. Evaluation and Analysis of New-Energy Vehicle Industry Policies in the Context of Technical Innovation in China. J. Clean. Prod. 2021, 281, 125126. [CrossRef]

57. Kuang, B.; Han, J.; Lu, X.; Zhang, X.; Fan, X. Quantitative Evaluation of China's Cultivated Land Protection Policies Based on the PMC-Index Model. Land Use Policy 2020, 99, 105062. [CrossRef]

58. Wu, W.H.; Sheng, L.Y.; Tang, F.C.; Zhang, A.M. Quantitative evaluation of manufacturing innovation policy based on feature analysis. Stud. Sci. Sci. 2020, 38, 46-57.

59. Zhang, Y.A.; Zhou, Y.Y. New energy vehicle subsidy policy tool mining and quantitative evaluation. China Popul. Resour. Environ. 2017, 27, 88-97.

60. Pan, D.; Chen, H.; Kong, F.B. Study on the evolution characteristics and laws of China's forestry policy since 1949-Based on the quantitative analysis of 283 forest-related normative documents. Chin. Rural Econ. 2019, 7, 89-108. 